\title{
GENETIC STRUCTURE OF THE SHEEP FROM THE BULGARIAN DAIRY SYNTHETIC POPULATION ON THE EXPERIMENTAL FARM OF THE AGRICULTURAL INSTITUTE IN SHUMEN
}

\author{
Nevyana Stancheva ${ }^{1}$, Jivko Krastanov ${ }^{2}$, Teodora Angelova ${ }^{2}$, Georgi Kalaydhziev ${ }^{2}$, \\ Daniela Yordanova ${ }^{2}$, Stayka Laleva ${ }^{2}$ \\ ${ }^{1}$ Agricultural Institute, 9700 Shumen, Bulgaria \\ ${ }^{2}$ Agricultural Institute, 6000 Stara Zagora, Bulgaria \\ nevqna_68@abv.bg
}

\begin{abstract}
Objective of the study was to establish the present generated genetic structure in the sheep from the nucleus herd of the Bulgarian Dairy Synthetic Population on the Experimental Farm of Agricultural Institute - Shumen. Subject of study are the ewes borne during the period 2007-2012 with available records for the main selection traits milk yield and prolificacy. On the basis of the information from the pedigree books was build up a database of the pedigrees of 601 ewes. For each individual was constructed a genetic code representing the breed belonging of the ancestors back to third pedigree level. The established genotypes are formed with the participation of the breeds: $1-$ Bulgarian Dairy Synthetic Population; 2 - Lacaune; 3 - Chios; 4 - East Friesian; 9 - with unknown pedigree. For the particular period of study, the genetic structure of the herd is formed by 33 genotypes. The highest portion of $78.21 \%$ is that of the ewes produced by linebreeding, shared by the BDSP genotype (53.91\%) and those with genetic component from EF (24.3\%). The $\mathrm{F}_{1}$ crossbreds with Lacaune and Chios (9.99 and 3.33\%), the genotypes of the offspring resulted from them after mating with BDSP rams $(2.16,1.16$ and $0.33 \%)$, and those of unknown pedigree from the side of one of the parents $(1.83 \%)$ do not affect the overall genetic structure of the herd. With regard to the degree of grading from the different breeds, there are 15 genetic groups formed in the herd. The established variability of genotypes and genetic groups is to be grounded on the principle of forming the scientific hypothesis for evaluation of the genetic effects - additive and non-additive. Disregarding the non-additive genetic component in the process of crossbreeding would result in biased estimate of the genetic variability and in wrong prediction for the further development of the genetic structures of the population.
\end{abstract}

Key words: sheep; Bulgarian Dairy Synthetic Population; genotype; genetic structure; genetic group

\section{ГЕНЕТСКА СТРУКТУРА НА ОВЦИТЕ ОД БУГАРСКАТА МЛЕЧНА СИНТЕТИЧКА ПОПУЛАЦИЈА ВО СТАДОТО НА ЕКСПЕРИМЕНТАЛНАТА ФАРМА НА ЗЕМЈОДЕЛСКИОТ ИНСТИТУТ ВО ШУМЕН}

Целта на проучувањето беше да се утврди сегашната генерирана генетска структура на овците од нуклеус-стадото на бугарската млечна синтетичката популација (БМСП) на експерименталната фарма на Земјоделскиот институт во Шумен. Објектот на истражувањето беа мајките родени во периодот 2007 - 2012 година, за коишто има регистрирана продуктивност според основните селекциски признаци - млечност и плодност. Според информациите од книгите со опис на потеклото е создадена база на податоци за педигреата на 601 овца. За секоја поединечна индивидуа е оформен генетски код во однос на расовата припадност на родителите до трета генерација. Утврдени се генотипови со учество на: 1 - бугарска млечна синтетичка популација, 2 - лакон, 3 - хиос, 4 - источнофризиска раса (ИФ), 9 - животни со непознато потекло. За конкретниот период, генетската структура во проучуваното стадо е формирана од 33 генотипа. Со најголемо присуство се претставени овците-мајки, кои се производ на внатрешно линеарно одгледување $(78,21 \%)$, од кои $53,91 \%$ се со генотип на БМСП и $24,3 \%$ се со генетска компонента од расата ИФ во генотипот. Добиените $\mathrm{F}_{1}$ мелези со расите лакон и хиос $(9,99 \%$ и $3,33 \%)$, генотиповите кои се потомство на овните од линиите на БМСП $(2,16 \%$, $1,66 \%$ и $0,33 \%)$ и тие со непознато потекло на едниот од двата родитела $(1,83 \%)$ не покажуваат влијание врз целосната структура на стадото. Во зависност од процентот на крв кај одделните раси во стадото, оформени се 15 генетски групи. Утврденото разнообразие од генотипови и генетски групи треба да биде искористено при формирање на научната хипотеза за оценување на генетските ефекти - адитивни и неадитивни. Доминацијата на неадитивната генетска компонента во процесот на вкрстување би довела до изместување на оцената 
на генетското разнообразие и до погрешна прогноза на идниот развој на генетските структури на популацијата.

Клучни зборови: овци; бугарска млечна синтетичка популација; генотип; генетска структура; генетска група

\section{INTRODUCTION}

Combining the specific characteristics of certain breeds for higher productivity and genetic gain is traditionally applied in sheep breeding, and the end new breeds, populations and lines are classified as composite ones (Rasali et al., 2006; Walkom et al., 2011). Exemplary is the Bulgarian Dairy Synthetic Population (BDSP), registered under certificate N10645 from June 30, 2005. In the national sheep breed structure, this population is most highly presented. It has been accomplished through the implementation of various schemes of continuous hybridization (Hinkovski et al., 1979, 1984), the focus being on the possibility for "synthesizing" an "additive" component for high milk yield and prolificacy with manifestation of heterosis in these traits as a result of the gene interaction that takes place in such a method of crossing. In the schemes, for basis have been used ewes from Bulgarian fine-fleece, semi fine-fleece and dairy breeds, while for paternal side have been selected rams from the highly productive dairy breeds - the imported East Friesian (EF) and Awassi (Aw), and the national Pleven Blackheaded Sheep (BHP) and Stara Zagora Sheep (SZ). Evaluations of the different crosses outcoming from the different levels of hybridization have been carried out by an array of researchers (Hinkovski et al., 1979,1982; Boikovski, 1982; Dimitrov, 1986; Vitkov, 1987; Tzvetanov, 1989; Djorbineva et al., 1995; Dimov, 1995; Petrova and Vitkov, 1996; Laleva et al., 1997; Lazarov et al., 2002; Nedelchev et al., 2003). In the separate sire producing flocks has been applied thorough-breeding. In dependence on the schemes practiced in the different country regions, phenotypic differences are apparent among the animals. At present, the most typical and consolidated herds from the National Genetic Pool of the BDSP are in the livestock institutes and experimental stations in the system of Agricultural Academy: Experimental Farm of Agricultural Institute - Shumen (EFAI); Institute of Animal Science - Kostinbrod; Agricultural Institute - Stara Zagora; and Institute of Agriculture - Karnobat, Agricultural experimental station - Vidin (Stancheva et al., 2014).

The BDSP flock bred on the Experimental Farm of Agricultural Institute - Shumen is presented as a main sire producing herd. It was founded in 1978, its development undergoing a specific modified scheme with selection conducted for dairy traits, prolificacy and maintaining of wool productivity. The ewes from the North-East Bulgarian Fine-Fleece breed, used as maternal basis, have been mostly bred to EF rams with indirect blood introduction from Aw, BHP, and subsequently from SZ. The development of the today distinct genealogical structure in the herd, which started to form since the first steps of crossing, has passed through several periods. Line breeding, using rams produced in the herd, has been conducted for more than thirty years, applying homogenous selection combined with moderate inbreeding. The results of the permanent selection process of the BDSP sheep of Experimental Farm of Agricultural Institute in Shumen are subject of regular analyses and research. The phenotypic and genetic parameters of productivity, the genealogical structure, the composition and properties of milk, the applied matting selection, and the fattening performance of lambs are under control (Boikovski et al., 2002 $2002^{\mathrm{b}}, 2003^{\mathrm{a}}, 2003^{\mathrm{b}}, 2005,2006$; Stancheva, 2002; Stancheva, 2003; Stancheva et al., 2006; Stancheva et al., 2011; Stancheva and Staykova 2013). Stancheva (2013) carried out a research on the main productive traits of the BDSP sheep born in the period 2004-2008, establishing lower heritability estimates after the certification of the breed. The author states the opinion that the dynamics of the estimated genetic variance are attributed to the targeted selection, to the interaction between genotype and environment, to the strict adherence to selection limits and the implementation of "selection press". After 2007, two selection trials have been carried out for inducing genetic variability and introduction of components for high milk yield from the Lacaune and Chios breeds. In her subsequent study on the parameters of the productive traits as dependant on lineage, Stancheva et al., (2014) reported that the highest mean 120-day milk yield of the ewes from the herd belongs to the Chios crosses, at first lactation being by $26 \%$ and at second by $15 \%$ higher than that of the BDSP lines. Similar are the results concerning biological prolificacy, in the Chios-blooded ewes at $2.5 \mathrm{yr}$ being 1.56 , at $3.5 \mathrm{yr}-1.67$, and at $4.5 \mathrm{yr}-1.90$, compared to those from the developed BDSP lines where the respective values are 1.27, 1.42, and 1.49 .

The cited results afford the hypothesis that the intense selection, the long-term line breeding, the 
introduction of new genetic components from the breeds Lacaune and Chios, along with the specific genetic effects lead to alteration of the genetic structure and the variability of the main selection traits in the herd. This calls for up-to-date analysis of the new genetic variation and for a basis for unbiased evaluation of the genetic effects (additive and non-additive) in terms of the applied methods and breeding schemes and their further development.

The objective of the present study was to establish the present generated genetic structure in the sheep from the nucleus herd of the Bulgarian Dairy Synthetic Population at Agricultural Institute in Shumen.

\section{MATERIAL AND METHODS}

Subject of study were the ewes of the Bulgarian Dairy Synthetic Population from the herd of the Agricultural Institute in Shumen, borne within 2007-2012 with available records for the main productive traits - milk yield and prolificacy. For the aim of the study, the set of information from the individual identity books was systematized and a database was build up regarding the heterogeneity (pedigree by lineage) of the individuals (genotypes) by entering genetic codes based on the pedigree data, representing the breed belonging (lineage) of the ancestors back to third pedigree level including. The genetic code of an individual used in our study consists of eight digits, each digit representing a genetic code of an ancestor and the combination of all digits - the per se genotype of the proband.

In the database of the pedigrees of the BDSP ewes the breeds involved in the schemes of development of the studied herd, the thorough-bred individuals, and the breeds that took part in the trials for introduction of genetic material for high milk yield and prolificacy are denoted with the following codes: 1 - Bulgarian Dairy Synthetic Population (BDSP); 2 - Lacaune (Lc); 3 - Chios (Ch); 4 East Friesian (EF); 9 - unknown pedigree from the side of one of the parents (UP).

The first four digits in each individual code represent the genotype of the dam, and the next four - that of the sire.

All actual relations among the individuals were established and as a result the matrix of relatives consists of 878 individuals (pedigrees), 277 of them basal and 601 non basal.
On the base of the obtained information were established the genotypes of the individuals in the herd and the number of the individuals with analogous genotype. From the participation of the different breeds in the formation of the genotype of each individual, consequently were established the breed groups in the herd. The percentage of grading herein is denoted with subscript (e.g. BDSP $_{87.5}$ meaning $87.5 \%$ blood from BDSP).

\section{RESULTS AND DISCUSSION}

The results indicate that for the particular period of study, 33 genotypes have been formed in the herd (Table 1).

From the overall dataset most numerous are the genotypes of the ewes product of thorough breeding within BDSP ( 324 heads), followed by those bearing the genetic component of EF within third pedigree level (146 heads). This is a reasonable consequence of the applied linebreeding with rams produced in the herd, and hence of the highly presented analogous information (homozygosity) in the genetic code of the progeny. Certain alteration of the genotypes occurs after the selection trials for improving the genetic variability and introduction of components for high milk yield and prolificacy from $\mathrm{Ch}$ and Lc. It should be qualified that subjected to crossing have been ewes with high degree of relationship with the active rams in the herd and those ewes with unknown pedigree (from the side of one of the parents), hence resulting in $F_{1}$ crosses with genotypes formed by the respective breeds (20 $\mathrm{Ch}$ and $60 \mathrm{Lc}$ crossbreds). The latter crosses have been further bred to BDSP rams to form new genotypes differently graded by the breeds involved in the trial.

Figure 1 shows the percentage (relative frequency) of the genotypes existing in the herd. Highest is the portion of the animals with BDSP genotype $-53.91 \%$. Second highest are the ewes product of linebreeding, with genetic component from $\mathrm{EF}$ in their genotype. These animals constitute $24.3 \%$ of the herd structure. The $\mathrm{F}_{1}$ crossbreds of the Lc and Ch breeds are respectively 9.99 and $3.33 \%$. The portion of the genotypes of the offspring resulted from them after mating with BDSP rams is 2.16 and $1.16 \%$ respectively. The percentage of the genotypes formed by crossing BDSP individuals with the breeds $\mathrm{Ch}$ and $\mathrm{Lc}$ is $1.83 \%$, while those of unknown ancestry constitute $2.49 \%$. There are also two genotypes $(0.33 \%)$ resulted from a BDSP dams and BDSP $\times$ Lc sires. 
Table 1

Genetic structure of the BDSP ewes from the Experimental Farm of the Agricultural Institute in Shumen by breed

\begin{tabular}{|c|c|c|c|c|c|c|c|c|c|c|}
\hline \multirow{2}{*}{ № } & \multirow{2}{*}{ Established genotypes } & \multicolumn{7}{|c|}{ Distribution by year of birth, heads } & \multirow{2}{*}{$\begin{array}{l}\text { Total for the period, } \\
\text { heads }\end{array}$} & \multirow{2}{*}{$\begin{array}{c}\text { Percentage } \\
\%\end{array}$} \\
\hline & & 2006 & 2007 & 2008 & 2009 & 2010 & 2011 & 2012 & & \\
\hline 1 & 11111111 & 81 & 16 & 47 & 54 & 55 & 70 & 1 & 324 & 53,91 \\
\hline 2 & 11111114 & 2 & 0 & 0 & 0 & 0 & 0 & 0 & 2 & 0,33 \\
\hline 3 & 11111122 & 0 & 0 & 0 & 0 & 2 & 0 & 0 & 2 & 0,33 \\
\hline 4 & 11111144 & 8 & 0 & 2 & 1 & 0 & 0 & 0 & 11 & 1,83 \\
\hline 5 & 11111411 & 0 & 7 & 16 & 6 & 5 & 0 & 0 & 34 & 5,66 \\
\hline 6 & 11112222 & 0 & 0 & 17 & 14 & 1 & 8 & 1 & 41 & 6,82 \\
\hline 7 & 11113333 & 0 & 10 & 4 & 1 & 0 & 0 & 0 & 15 & 2,50 \\
\hline 8 & 11141111 & 3 & 4 & 2 & 3 & 5 & 10 & 0 & 27 & 4,49 \\
\hline 9 & 11141114 & 0 & 1 & 0 & 0 & 0 & 0 & 0 & 1 & 0,17 \\
\hline 10 & 11141144 & 7 & 0 & 2 & 0 & 0 & 0 & 0 & 9 & 1,50 \\
\hline 11 & 11141411 & 0 & 0 & 0 & 2 & 2 & 0 & 0 & 4 & 0,67 \\
\hline 12 & 11141414 & 2 & 0 & 0 & 0 & 0 & 0 & 0 & 2 & 0,33 \\
\hline 13 & 11142222 & 0 & 0 & 3 & 3 & 2 & 1 & 0 & 9 & 1,50 \\
\hline 14 & 11143333 & 0 & 3 & 0 & 0 & 0 & 0 & 0 & 3 & 0,50 \\
\hline 15 & 11221111 & 0 & 0 & 0 & 0 & 2 & 8 & 0 & 10 & 1,66 \\
\hline 16 & 11221122 & 0 & 0 & 0 & 0 & 1 & 0 & 0 & 1 & 0,17 \\
\hline 17 & 11229999 & 0 & 0 & 0 & 0 & 0 & 1 & 1 & 2 & 0,33 \\
\hline 18 & 11331111 & 0 & 0 & 0 & 0 & 7 & 6 & 0 & 13 & 2,16 \\
\hline 19 & 11332222 & 0 & 0 & 0 & 7 & 0 & 0 & 0 & 7 & 1,16 \\
\hline 20 & 11441111 & 5 & 0 & 3 & 0 & 0 & 0 & 0 & 8 & 1,33 \\
\hline 21 & 11441114 & 0 & 1 & 1 & 0 & 0 & 0 & 0 & 2 & 0,33 \\
\hline 22 & 11441144 & 8 & 0 & 1 & 0 & 0 & 0 & 0 & 9 & 1,50 \\
\hline 23 & 11441411 & 0 & 0 & 0 & 0 & 1 & 0 & 0 & 1 & 0,17 \\
\hline 24 & 13221111 & 0 & 0 & 0 & 0 & 0 & 4 & 0 & 4 & 0,67 \\
\hline 25 & 14111111 & 2 & 0 & 2 & 5 & 9 & 4 & 0 & 22 & 3,66 \\
\hline 26 & 14111144 & 0 & 4 & 1 & 0 & 1 & 0 & 0 & 6 & 1,00 \\
\hline 27 & 14111411 & 0 & 0 & 1 & 3 & 1 & 0 & 0 & 5 & 0,83 \\
\hline 28 & 14112222 & 0 & 0 & 3 & 3 & 3 & 0 & 0 & 9 & 1,50 \\
\hline 29 & 14113333 & 0 & 0 & 2 & 0 & 0 & 0 & 0 & 2 & 0,33 \\
\hline 30 & 14141144 & 0 & 0 & 2 & 0 & 0 & 0 & 0 & 2 & 0,33 \\
\hline 31 & 14141411 & 0 & 0 & 0 & 0 & 1 & 0 & 0 & 1 & 0,17 \\
\hline 32 & 99991122 & 0 & 0 & 0 & 0 & 6 & 0 & 0 & 6 & 1,00 \\
\hline \multirow[t]{2}{*}{33} & 99992222 & 0 & 0 & 1 & 1 & 3 & 2 & 0 & 7 & 1,16 \\
\hline & total & 118 & 46 & 110 & 103 & 107 & 114 & 3 & 601 & 100,00 \\
\hline
\end{tabular}

*1 - BDSP; 2 - Lacaune; 3 - Chios; 4 - East Friesian; 9 - unknown

**The initial four digits represent the genotypes of the maternal side, and the next four - of the paternal 


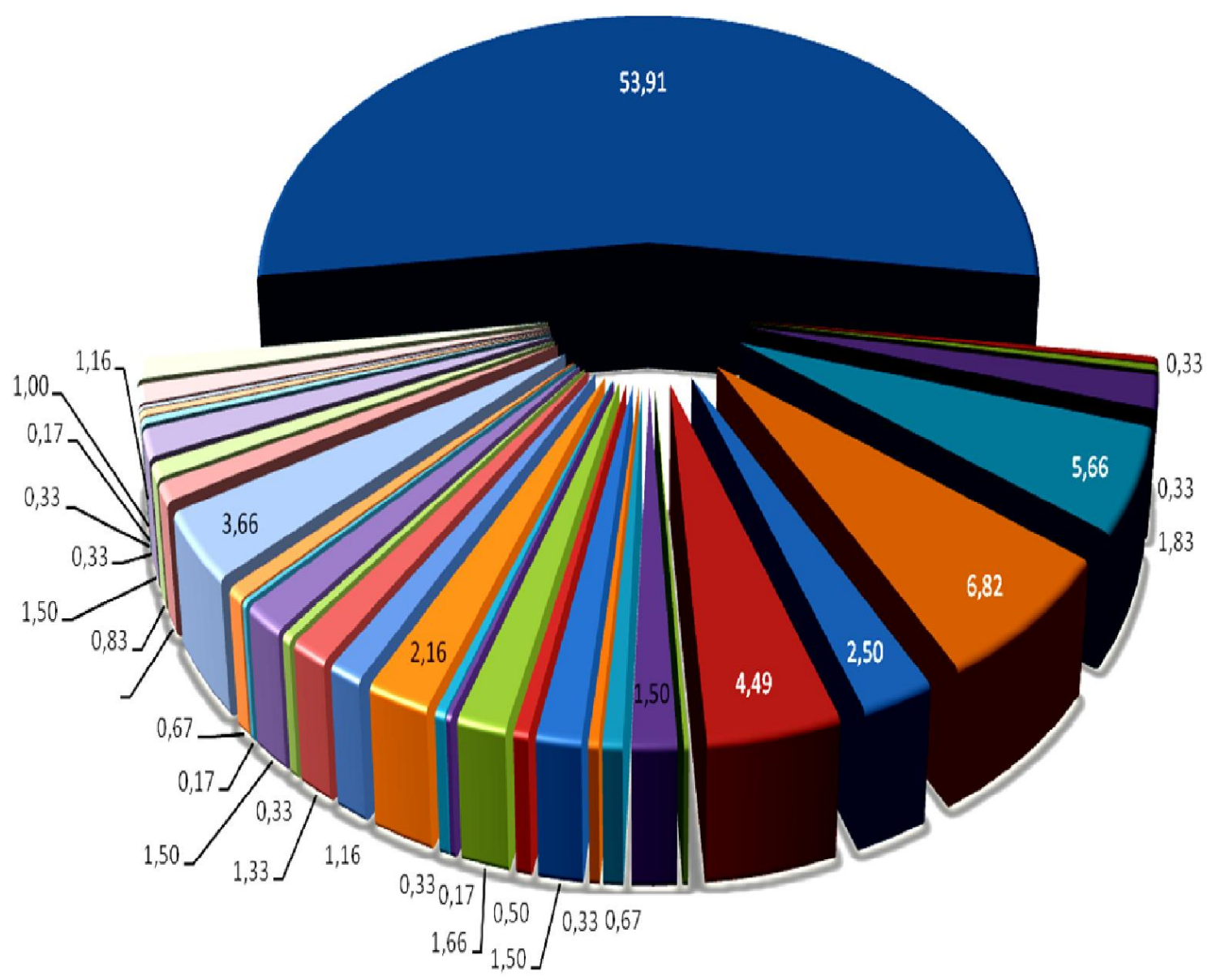

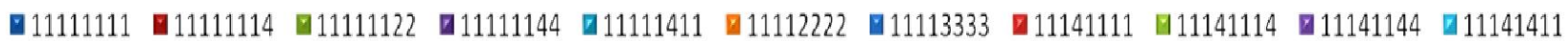

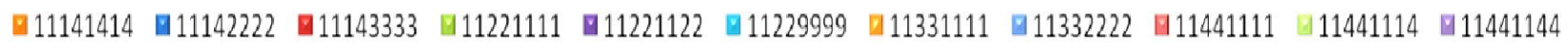

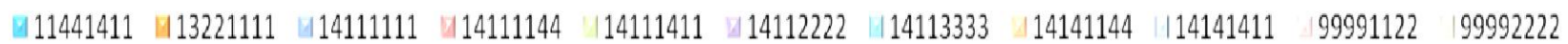

Fig. 1. Percentage of established genotypes of the BDSP ewes from the Experimental Farm of the Agrocultural Institute in Shumen

The analysis of the registered genotypes indicates that, with regard to the degree of grading from the different breeds, there are 15 genetic groups formed in the herd (Table 2). The existing variability within each group is a result of the positioning of the breed symbols in the codes of the individuals. Reasonably highest is the portion of the 100-percent BDSP ewes $\left(\mathrm{BDSP}_{100}\right)-53.91 \%$. Next are the groups of $\mathrm{BDSP}_{87.5} / \mathrm{EF}_{12.5}(87.5 \%$ $\mathrm{BDSP}$ and $12.5 \% \mathrm{EF}$ graded genotype) represented with $14.4 \%, \mathrm{BDSP}_{50} / \mathrm{Lc}_{50}$ with $6.99 \%, \mathrm{BDSP}_{75} /$ $\mathrm{EF}_{25}$ with $4.83 \%, \mathrm{BDSP}_{62.5} / \mathrm{EF}_{37.5}$ with $3.49 \%$, and $\mathrm{Lc}_{50} / \mathrm{BDSP}_{37.5} / \mathrm{EF}_{12.5}$ with $3 \%$. The rest of the genetic groups constitute from $0.67 \%\left(\mathrm{BDSP}_{62.5} / \mathrm{Lc}_{25} /\right.$ $\left.\mathrm{Ch}_{12.5}\right)$ to $2.5 \%\left(\mathrm{BDSP}_{50} / \mathrm{Ch}_{50}\right)$. Noteworthy is that the $\mathrm{BDSP}_{50} / \mathrm{EF}_{50}$ ewes $(1.83 \%)$ are not $\mathrm{F}_{1}$ crossbreds but linebreds, their degree of grading from the EF breed being an outcome of the expression of the genotypes of the ancestors from the second and third pedigree level.

This study is the first concerning the herd on the Experimental Farm of Agricultural Institute in Shumen in particular and the BDSP as a whole after its certification as a breed, and it confirms the thesis that this herd is a consolidated and typical BDSP herd. An appropriately targeted future selection necessitates further investigations and analyses regarding the expression of the different genotypes and genetic groups for the main selection traits. 
Table 2

Genetic groups of the BDSP ewes from the Experimental Farm of Agricultural Institute - Shumen

\begin{tabular}{|c|c|c|c|c|}
\hline $\begin{array}{l}\text { Genetic } \\
\text { group, № }\end{array}$ & $\begin{array}{l}\text { Percentage of grading from the different } \\
\text { breeds into the genotype }\end{array}$ & Genotypes & $\begin{array}{l}\text { Individuals in the group, } \\
\text { heads }\end{array}$ & $\begin{array}{l}\text { Percentage, } \\
\%\end{array}$ \\
\hline 1 & $100 \%$ BDSP & 11111111 & 324 & 53,91 \\
\hline \multirow{4}{*}{2} & \multirow{4}{*}{$87 \%$ BDSP $12,5 \%$ EF } & 11111114 & \multirow{4}{*}{85} & \multirow{4}{*}{14,14} \\
\hline & & 11111411 & & \\
\hline & & 11141111 & & \\
\hline & & 14111111 & & \\
\hline \multirow{5}{*}{3} & \multirow{5}{*}{$75 \% \mathrm{BDSP} 25 \% \mathrm{EF}$} & 11111144 & \multirow{5}{*}{29} & \multirow{5}{*}{4,83} \\
\hline & & 11441111 & & \\
\hline & & 11141114 & & \\
\hline & & 11141411 & & \\
\hline & & 14111411 & & \\
\hline \multirow{6}{*}{4} & \multirow{6}{*}{$62,5 \%$ BDSP $37,5 \%$ EF } & 11141144 & \multirow{6}{*}{21} & \multirow{6}{*}{3,49} \\
\hline & & 14111144 & & \\
\hline & & 11441114 & & \\
\hline & & 11441411 & & \\
\hline & & 11141414 & & \\
\hline & & 14141411 & & \\
\hline \multirow{2}{*}{5} & \multirow{2}{*}{$50 \%$ BDSP $50 \% \mathrm{EF}$} & 11441144 & \multirow{2}{*}{11} & \multirow{2}{*}{1,83} \\
\hline & & 14141144 & & \\
\hline \multirow{2}{*}{6} & \multirow{2}{*}{$50 \%$ BDSP $50 \%$ Lc } & 11112222 & \multirow{2}{*}{42} & \multirow{2}{*}{6,99} \\
\hline & & 11221122 & & \\
\hline \multirow{2}{*}{7} & \multirow{2}{*}{ 75\%СПБМ 25\%Лакон } & 11111122 & \multirow{2}{*}{12} & \multirow{2}{*}{2,00} \\
\hline & & 11221111 & & \\
\hline 8 & $50 \%$ BDSP $50 \% \mathrm{Ch}$ & 11113333 & 15 & 2,50 \\
\hline 9 & 75\%BDSP 25\%Chios & 11331111 & 13 & 2,16 \\
\hline 10 & $62,5 \%$ BDSP $25 \%$ Lc $12,5 \% \mathrm{Ch}$ & 13221111 & 4 & 0,67 \\
\hline \multirow{2}{*}{11} & \multirow{2}{*}{$50 \%$ Lc $37,5 \%$ BDSP $12,5 \%$ EF } & 11142222 & \multirow{2}{*}{18} & \multirow{2}{*}{3,00} \\
\hline & & 14112222 & & \\
\hline 12 & $50 \%$ Lc $25 \%$ BDSP $25 \% \mathrm{Ch}$ & 11332222 & 7 & 1,16 \\
\hline \multirow{2}{*}{13} & $50 \% \mathrm{Ch} 3750 \mathrm{BDSP} 125 \% \mathrm{FF}$ & 11143333 & 5 & 083 \\
\hline & $50 \%$ Ch 3/,5\%BDSP 12,5\%ЕF & 14113333 & 5 & 0,83 \\
\hline 14 & $50 \%$ Unknown 25\%RDSP $25 \% \mathrm{~L}$ & 11229999 & 8 & 133 \\
\hline 17 & 法 & 99991122 & 0 & 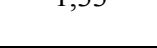 \\
\hline 15 & $50 \%$ Unknown $50 \%$ Lc & 99992222 & 7 & 1,16 \\
\hline & & Total & 601 & 100 \\
\hline
\end{tabular}

\section{CONCLUSIONS}

For the studied period in particular, the genetic structure of the herd is composed of 33 genotypes. The highest portion of $78.21 \%$ is that of the ewes produced by line-breeding, shared by the BDSP genotype $(53.91 \%)$ and those with genetic component from EF (24.3\%).
The $\mathrm{F}_{1}$ crosses with Lacaune and Chios (9.99 and $3.33 \%$ ), the genotypes of their progeny after crossing with the rams from the BDSP lines (2.16, 1.66 and $0.33 \%$ ) and those with unknown pedigree from the side of one of the parents $(1.83 \%)$ do not have impact on the overall herd structure.

In dependence on the percentage of grading from the different breeds into the registered geno- 
types, 15 genetic groups have been formed in the herd. The existing variability within the separate groups is an outcome of the position of the breed symbol in the genetic code of the individuals.

Our study is the first concerning this herd in particular and the BDSP as a whole after its certification as a breed. The established variability of genotypes and genetic groups is to be grounded on the principle of forming the scientific hypothesis for evaluation of the genetic effects - additive and non-additive. Disregarding the non-additive genetic component in the process of crossbreeding would result in biased estimate of the genetic variability and in wrong prediction for the further development of the genetic structures of the population.

\section{REFERENCES}

[1] Boikovski, S.: Results of an absorbing crossbreeding of Black-Head Plevenska and fine-fleece North-East Bulgarian, Shumen type, ewes with Avasi rams. I. Productivity of F1 crossbreds, Animal Science XIX (5), 12-17 (Bg) (1982).

[2] Boikovski, St., N. Stancheva, G. Stefanova, D. Dimitrov:. Composition and properties of the milk in the sheep from Newly Created synthetic populatation in Bulgaria, Bulgarian Journal of Agricultural Science, 8, (2-3), pp 289$293\left(2002^{\mathrm{a}}\right)$.

[3] Boikovski, St., N. Stancheva, G. Stefanova, D. Dimitrov: Fattening Abilities of Lambs from the Newly Created Milk Sheep Breed in Bulgaria, Bulgarian Journal of Agricultural Science, 8, 5-6, 645-648 (2002 $\left.{ }^{\mathrm{b}}\right)$.

[4] Boikovski, St., N. Stancheva, G. Stefanova, D. Dimitrov: Influence of Some Factors of the Milk Composition and the Yield of Trait of Sheep from The Newly Created Milk Sheep Breed, Bulgarian Journal of Agricultural Science, 9, 2, pp 243-249 (2003 $)$.

[5] Boikovski, St., N. Stancheva, G. Stefanova, D. Dimitrov: Influence of Some Factors on Biological Prolificacy in Sheep from the Newly Created Milk Sheep Breed, Bulgarian Journal of Agricultural Science, 9, 3, pp 391-395 $\left(2003^{\mathrm{b}}\right)$.

[6] Boikovski, St., N. Stancheva, G. Stefanova, D. Dimitrov: Milk Composition of the Sheep from Newly Created Milk Sheep Breed, Bulgarian Journal of Agricultural Science, 5, 619-632 (2005).

[7] Boikovski, St., G. Stefanova, N. Stancheva: Milk Yield for milking period in the Sheep from the Newly Created Milk Breed in Bulgaria, Bulgarian Journal of Agricultural Science, 12, 1, 145-152 (2006).

[8] Dimitrov, Em.: Creation of Milk Sheep Breeding in Sofia District. Ph D Thesis, Sofia, 1986, 164 p. (Bg).

[9] Dimov, D.: Results of the Study on Applied Breeding Schemes for Creating Dairy Sheep. Ph D Thesis, Sofia, 1995. 145 p. (Bg).

[10] Djorbineva M. T. Dimitrov, G. Mihailova, I. Dimitrov, I. Ivanov: Variability of milk productivity, milk composi- tion and quality in sheep of Stara Zagora breed and crossbreds by East Frisian rams at second lactation. Animal Science № 3-4; 83-86 (1995) (Bg).

[11] Hinkovski, Tz., P. Donchev, D. Dochevski:. Diary sheep breeding and sheep management technologies, Zemizdat, Sofia, 1979, 213 p. (Bg).

[12] Hinkovski, Tz., A. Stoyanov, P. Donchev, S. Boikovski, V. Tzvetanov, E. Todorova and D. Nasev: Creation of high milk sheep breeding - conditions for specialized use of sheep. Coll. Increasing the production of milk and meat in sheep, Sofia, pp. 3-18 (1982) (Bg).

[13] Hinkovski, Tz., A. Stoyanov, P. Donchev and S. Boikovski: Methodical instructions for creation of synthetic sheep population and technologies of raisin. Agric. Academy, Sofia, 1984, 37 p. (Bg).

[14] Lazarov, V., L. Mihailova, M. Iliev: Creation of population of sheep with increased milk yield. Animal Science, № 6, 11-13 (2002) $(\mathrm{Bg})$.

[15] Laleva, S., M. Jorbineva: Fertility of Dairy type sheep dams. Animal Science, № 7-8, pp 5-7 (1997) (Bg).

[16] Nedelchev, D., E. Raicheva, Y. Petrova: Characteristics of the productivity of dairy sheep crosses. Animal Science, № 3-4, pp 111-114 (2003) (Bg).

[17] Petrova, Y., and V. Vitkov: Comparative characteristic of the milk yield of sheep from the Black-headed Pleven sheep and its crosses with the Awassi and the East Friesian breed. Animal Breeding, 33 (5), pp 25-28 (1996) (Bg).

[18] Rasali, D. P., J. N. B. Shrestha, and G. H. Crow: Development of composite sheep breeds in the world. Canadian Journal of Animal Science, 86 (1), pp 1-24, 10. 4141/A05-073 (2006)

[19] Stancheva, N.: Optimal live weight and productivity of the sheep from newly created milk sheep breed, Bulgarian Journal of Agricultural Science, 8, (4), pp 421-428 (2002).

[20] Stancheva, N.: Phenotypic and Genotypic Parameters of Selection Indices in the Newly Created Milk Sheep Population in Bulgaria. Ph D Thesis, Sofia, 2003. 188 p. (Bg)

[21] Stancheva, N., St. Boikovski, G. Stefanova, D. Dimitrov, A. Rusenov: Regularities in lactation persistency of lactation and possibilities for using part of lactation in tribal work in ewes from Synthetic Population Bulgarian Milk. International Scientific Conference - Stara Zagora, Jine 1-2, Vol. 2. Vet. Medicine, Animal Studies. 244-247. 2006 (Bg).

[22] Stancheva N., N. Naidenova, G. Staikova: Physicochemical composition, properties, and technological characteristics of sheep milk from the Bulgarian Dairy Synthetic Population, Macedonian Journal of Animal Science, vol. 1, No 1, pp. 73-76 (2011).

[23] Stancheva, N.: Productive performance and heritability of some traits of the Synthetic Population Bulgarian Milk sheep, Journal of Animal Science, 6, 29-35 (2013) (Bg).

[24] Stancheva, N., G. Staykova: Body condition score and productive performance of the Synthetic Population Bulgarian Milk sheep, Journal of Animal Science, 6, 42-47 (2013) (Bg).

[25] Stancheva N., I. Dimitrova, S. Georgieva: Biological fertility and milk yield in Bulgarian Dairy Synthetic Population sheep according to breeding line. Agricultural Science and Technology, vol. 6, No 1, pp 17-20 (2014). 
[26] Stancheva, N., E. Raicheva, S. Laleva, T. Ivanova, M. Iliev, G. Kalaydhziev: Present status, problems and development of the Synthetic Population Bulgarian Milk sheep from the herds of Agricultural Accademy, Journal of Animal Science, 6, 3-11 (2014) (Bg).

[27] Tzvetanov, V.: Study on the Breeding Effect in the Beginning of Creation Synthetic Sheep Population for Milk. $\mathrm{PhD}$ Thesis, Agric. Academy, SSCA., Sofia, 153 pp. (Bg).
[28] Vitkov, V.: Zootechnical Characteristic of the Productivity of Milk Sheep from Blackhead Pleven Breed and its Crosses With the Breeds Eastern Friesian and Awasi on Equal and Changing Level of Feeding. Ph D Thesis, Sofia, 1987. 153 p. (Bg).

[29] Walkom, S. F., A. P. Verbyla, F. D. Brien, M. L. Hebart and W. S. Pitchford: Partitioning genetic variance in composite sheep, Proc. Assoc. Advmt. Anim. Breed. Genet. 19: 91-94 (2011). 